\title{
Weed Control with Halosulfuron Applied Preplant Incorporated, Preemergence or Postemergence in White Bean
}

\author{
${\text { Nader Soltani }{ }^{*} \text {, Robert E. Nurse }}^{2}$, Christy Shropshire ${ }^{1}$, Peter H. Sikkema1 \\ ${ }^{1}$ University of Guelph Ridgetown Campus, Ridgetown, Ontario, Canada \\ ${ }^{2}$ Agriculture and Agri-Food Canada, Harrow, Ontario, Canada \\ Email: 'soltanin@uoguelph.ca
}

Received 27 June 2014; revised 28 July 2014; accepted 10 August 2014

Copyright (C) 2014 by authors and Scientific Research Publishing Inc.

This work is licensed under the Creative Commons Attribution International License (CC BY). http://creativecommons.org/licenses/by/4.0/

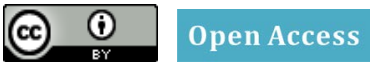

\section{Abstract}

Four field trials were conducted over a three-year period (2011-2013) at various locations in Ontario to evaluate the level of weed control provided by halosulfuron applied PPI, PRE or POST at 17.5, 35 and $70 \mathrm{~g} \cdot \mathrm{ai} \cdot \mathrm{ha}^{-1}$ in white bean. Halosulfuron applied PPI or PRE at 17.5, 35 and $35 \mathrm{~g} \cdot \mathrm{ai}^{\mathrm{i}} \cdot \mathrm{ha}^{-1}$ caused $2 \%$ or less visible injury 1 and 4 WAA in white bean. However, halosulfuron applied POST at $17.5,35$ and $70 \mathrm{~g} \cdot a i \cdot h a^{-1}$ caused $2 \%-8 \%$ and $1 \%-3 \%$ white bean injury at 1 and 4 WAA, respectively. There was no decrease in white bean seed yield relative to the weed free check due to weed interference with halosulfuron applied PPI or PRE at doses evaluated, except when applied PRE at $17.5 \mathrm{~g} \cdot \mathrm{ai}^{\circ} \mathrm{ha}^{-1}$ which resulted in a decrease in seed yield of $25 \%$. Weed interference caused a decrease in white bean yield of $47 \%, 42 \%$ and $44 \%$, when halosulfuron was applied POST at 17.5 , 35 and $70 \mathrm{~g} \cdot \mathrm{ai} \cdot \mathrm{ha}^{-1}$, respectively. Halosulfuron applied PPI, PRE and POST controlled AMARE 92\% $100 \%, 85 \%-99 \%$ and $47 \%-75 \%$; CHEAL $95 \%-100 \%, 83 \%-99 \%$ and $36 \%-51 \%$; and SINAR 97\% - 100\%, 99\% - 100\% and 100\%, respectively. Halosulfuron applied PPI and PRE reduced AMARE density 93\% - 97\% and 75\% - 95\%; CHEAL density 89\% - 98\% and $81 \%$ - 93\%; and SINAR density $99 \%-100 \%$ and $99 \%-100 \%$, respectively. Halosulfuron applied PPI and PRE reduced dry weight of AMARE 96\% - 98\% and 86\% - 96\%; CHEAL 96\% - 98\% and 87\% - 93\%; and SINAR 100\% and $100 \%$, respectively. Halosulfuron applied POST at rates evaluated reduced SINAR density and dry weight $100 \%$ but caused no significant reduction in AMARE and CHEAL density or dry weight compared to the weedy check. Based on these results, halosulfuron applied PPI or PRE at $35 \mathrm{~g} \cdot \mathrm{ai} \cdot \mathrm{ha}^{-1}$ can be used safely for the control of selected broadleaf weeds in white bean production.

\footnotetext{
"Corresponding author.
}

How to cite this paper: Soltani, N., Nurse, R.E., Shropshire, C. and Sikkema, P.H. (2014) Weed Control with Halosulfuron Applied Preplant Incorporated, Preemergence or Postemergence in White Bean. Agricultural Sciences, 5, 875-881. 


\section{Keywords}

\section{Efficacy, Dry Bean, Phaseolus vulgaris, Preemergence (PRE), Preplant-Incorporated (PPI), Postemergence (POST), Sensitivity, Tolerance}

\section{Introduction}

Ontario is one of the leading provinces in Canada in production of dry bean (Phaseolus vulgaris L.), producing 118,000 MT of dry bean on 49,000 hectares with a farm-gate value of approximately \$108 million in 2012 [1]. Major market classes of dry bean grown in Ontario include black, cranberry, kidney, and white (navy) bean. Dry beans are very sensitive to weed interference resulting in substantial yield losses [2]-[6]. In research conducted in Ontario the average yield loss due to weed interference in winter wheat was $2 \%$, in spring cereals $12 \%$, in soybean $40 \%$, in corn $52 \%$ and in dry beans $58 \%$ [7]. More research is needed to identify new weed management herbicide options that have an adequate margin of crop safety, provide consistent broad spectrum weed control, have low environmental impact and maximize dry bean yield and net returns.

Halosulfuron is a sulfonylurea herbicide that controls nutsedge species (Cyperus spp.), redroot pigweed (Amaranthus retroflexus L.), common lambsquarters (Chenopodium album L.), wild mustard (Sinapis arvensis L.), ladysthumb (Polygonum persicaria L.), velvetleaf (Abutilon theophrasti Medic.) and cocklebur (Xanthium strumarium L.), including triazine resistant biotypes [8]. Halosufuron is readily absorbed by roots and foliage and is translocated throughout the plant causing rapid growth inhibition in susceptible plants. Halosulfuron can be applied preplant incorporated (PPI), preemergence (PRE) or postemergence (POST). Injury symptoms in susceptible plants include chlorosis, death of the growing point and complete death within 14 - 21 days [7] [8]. Halosulfuron has low environmental impact as it is active at low doses, has low mammalian toxicity, and is relatively immobile in soils [7].

Halosulfuron will be available for the first time in the Ontario market during the 2014 field season. Halosulfuron will provide Ontario dry bean growers with a new, low-use-rate herbicide that provides full-season control of a number of annual broadleaf weeds. There is little information on the crop safety and efficacy of halosulfuron applied PPI, PRE and POST to control broadleaf weeds in dry bean under environmental conditions in Ontario.

The objective of this research was to evaluate the level of weed control provided by halosulfuron applied PPI, PRE or POST at $17.5,35$ and $70 \mathrm{~g} \cdot \mathrm{ai} \cdot \mathrm{ha}^{-1}$.

\section{Materials and Methods}

Field studies were conducted in 2011, 2012 and 2013 at the Huron Research Station, University of Guelph, Exeter, Ontario and in 2012 at the Agriculture and Agri-Food Canada Research Centre, Harrow, Ontario. The soil at Exeter was a Brookston clay loam (Orthic Humic Gleysol, mixed, mesic, and poorly drained) with 32\% sand, $42 \%$ silt, $26 \%$ clay, $3.7 \%$ organic matter and pH 7.8 in 2011 ; $41 \%$ sand, $35 \%$ silt, $24 \%$ clay, $3.2 \%$ organic matter and pH 7.9 in 2012; and 29\% sand, 44\% silt, 27\% clay, 3.6\% organic matter and pH 7.7 in 2013. The soil at Harrow was a Fox sandy loam (Brunisolic Gray Brown Luvisol) with 82.5\% sand, 5\% silt, 12.5\% clay, 2.6\% organic matter and $\mathrm{pH}$ of 6.0. Seedbed preparation at all sites consisted of fall moldboard plowing followed by two passes with a field cultivator in the spring.

The experiments were arranged in a two-way factorial design with four replications. Factor one was application timing (PPI, PRE, and POST) and Factor two was halosulfuron dose (17.5, 35 and $70 \mathrm{~g} \cdot \mathrm{ai}^{\mathrm{h}} \mathrm{ha}^{-1}$ ). Plots consisted of four rows of white "T9905" bean planted at a rate of 200,000 seeds ha ${ }^{-1}$ to a depth of $5 \mathrm{~cm}$ in rows that were spaced $0.75 \mathrm{~m}$ apart and were 8 or $10 \mathrm{~m}$ long in late May to early June of each year.

Herbicide treatments were made with a $\mathrm{CO}_{2}$-pressurized backpack sprayer calibrated to deliver $200 \mathrm{~L} \cdot \mathrm{ha}^{-1}$ of spray solution at a pressure of 200/240 kPa using low drift nozzles (ULD120-02, Spraying Systems Co., P.O. Box 7900. Wheaton, IL 60188). The boom was $1.5 \mathrm{~m}$ wide with four nozzles spaced $0.5 \mathrm{~m}$ apart. PPI, PRE, and POST (included nonionic surfactant at $0.25 \% \mathrm{v} / \mathrm{v}$ ) herbicides were applied 1 - 2 days before planting (incorporated immediately), 1 - 2 days after planting, and 3 - 4 weeks after planting ( 2 - 3 trifoliate leaf stage), respectively. Each replicate included a weedy and a weed-free check treatment. Weed-free check plots were main- 
tained with inter-row cultivation and hand hoeing during the growing season.

White bean injury and weed control were visually estimated on a scale of 0 (no injury/control) to $100 \%$ (complete plant death). White bean injury was assessed 1 and 4 weeks after emergence (WAE) for the PPI and PRE or 1 and 4 weeks (WAA) after POST treatment application. Weed control was assessed 4 and 8 WAA, respectively. Weed density and dry weight were evaluated 8 WAA by counting and cutting plants at the soil surface from two $0.5 \mathrm{~m}^{2}$ quadrats per plot and separating by species. Plants were dried at $60 \mathrm{C}$ to constant moisture (at least for 48 hours) and then weighed. White bean was considered mature when $90 \%$ of the pods in the weed-free check had turned from green to a golden colour. Beans were harvested from the two center rows of each plot with a small plot combine, weight and seed moisture content were recorded, and seed yields were adjusted to $18 \%$ seed moisture content.

Data were analyzed using PROC MIXED procedures in SAS 9.2. Herbicide treatment was considered a fixed effect, while environment (year-location combinations), the interaction between environment and herbicide treatment, and replicate nested within environment were considered random effects. Significance of the fixed effect was tested using F-test and random effects were tested using a Z-test of the variance estimate. The UNIVARIATE procedure was used to test data for normality and homogeneity of variance. For all ratings, any treatments assigned a value of zero (weedy and weed-free checks for crop injury; weedy check for weed control; weed-free check for weed density and dry weight) were excluded from the analysis. However, all values were compared independently to zero to evaluate treatment differences with the weedy and/or weed-free check. To satisfy the assumptions of the variance analyses, injury 1 and 4 WAA were square root transformed, weed control was arcsine square root transformed and weed density, dry weight and seed moisture content were $\log$ transformed. Treatment comparisons were made using Fisher's Protected LSD at a level of P $<0.05$. Data compared on the transformed scale were converted back to the original scale for presentation of results.

\section{Results and Discussion}

\subsection{Crop Injury}

The analysis of variance (ANOVA) indicated no effect of years or treatment by year interaction for crop injury; therefore, data were pooled and averaged for environments. Crop injury symptoms with halosulfuron included chlorosis, leaf necrosis and stunting of dry bean. Growth reduction was much greater with POST application.

Halosulfuron applied PPI or PRE at 17.5, 35 and $35 \mathrm{~g} \cdot$ ai $\mathrm{ha}^{-1}$ caused $2 \%$ or less visible injury 1 and 4 WAE in white bean (Table 1). However, halosulfuron applied POST at 17.5, 35 and 70 g.ai-ha ${ }^{-1}$ caused $2 \%-8 \%$ injury at 1 WAA and $1 \%-3 \%$ injury at 4 WAA in white bean (Table 1). In other studies, halosulfuron applied POST

Table 1. Percent visible injury 1 and 4 WAA, seed moisture content at harvest and seed yield of white bean treated with halosulfuron at three different timings at Exeter (2011-2013) and Harrow, ON (2012). Means followed by the same letter within a column are not significantly different according to Fisher's Protected LSD at $\mathrm{P}<0.05^{\mathrm{a}}$.

\begin{tabular}{|c|c|c|c|c|c|c|}
\hline \multirow[b]{2}{*}{ Herbicide Treatment } & \multicolumn{5}{|c|}{ Injury } & \multirow[b]{2}{*}{ Yield } \\
\hline & Rate $\mathrm{g} \cdot \mathrm{ai} \cdot \mathrm{ha}^{-1}$ & Timing & $1 \mathrm{WAE} / \mathrm{A}$ & $4 \mathrm{WAE} / \mathrm{A}$ & Seed Moisture & \\
\hline & & & \multicolumn{3}{|c|}{$\%$} & MT $\cdot \mathrm{ha}^{-1}$ \\
\hline Weedy check & & & $0 \mathrm{a}$ & 0 & 20.1 & $0.83 \mathrm{~d}$ \\
\hline Weed-free check & & & $0 \mathrm{a}$ & 0 & 18.8 & $2.60 \mathrm{a}$ \\
\hline Halosulfuron & 17.5 & PPI & $0 \mathrm{a}$ & 0 & 19.0 & $2.41 \mathrm{ab}$ \\
\hline Halosulfuron & 35 & PPI & $0 \mathrm{a}$ & 0 & 19.0 & $2.36 \mathrm{ab}$ \\
\hline Halosulfuron & 70 & PPI & $2 \mathrm{~b}$ & 2 & 18.8 & $2.21 \mathrm{ab}$ \\
\hline Halosulfuron & 17.5 & PRE & $0 \mathrm{a}$ & 1 & 19.1 & $1.94 \mathrm{bc}$ \\
\hline Halosulfuron & 35 & PRE & $0 \mathrm{a}$ & 1 & 18.8 & $2.15 a b$ \\
\hline Halosulfuron & 70 & PRE & $1 \mathrm{ab}$ & 2 & 19.1 & $2.13 \mathrm{ab}$ \\
\hline Halosulfuron & 17.5 & POST & $2 \mathrm{~b}$ & 3 & 19.6 & $1.38 \mathrm{~cd}$ \\
\hline Halosulfuron & 35 & POST & $3 \mathrm{~b}$ & 1 & 19.4 & $1.51 \mathrm{c}$ \\
\hline Halosulfuron & 70 & POST & $8 \mathrm{c}$ & 3 & 19.7 & $1.46 \mathrm{c}$ \\
\hline
\end{tabular}

${ }^{\mathrm{a}}$ Abbreviations: WAA, weeks after POST herbicide application; POST, postemergence; PPI, preplant incorporated; PRE, preemergence. 
caused $7 \%$ to $13 \%$ injury in black, cranberry, kidney, otebo, pinto, small red Mexican and white beans [9] [10], while in another study, halosulfuron applied alone or in combination with other herbicides caused as much as $6 \%$ injury in white bean [11]. Silvey et al. [12] reported 5\% injury from halosulfuron POST in snap bean. In contrast, other studies have shown significant injury in some market classes of dry bean with halosulfuron applied POST. Wall [13] reported as much as 50\% injury in white bean with halosulfuron applied POST. Stewart et al. [10] studying adzuki beans found as much as 67\% injury with halosulfuron POST at $35 \mathrm{~g} \cdot \mathrm{ai} \cdot \mathrm{ha}^{-1}$ and $86 \%$ injury with halosulfuron POST at $70 \mathrm{~g} \cdot \mathrm{ai}^{\mathrm{h}} \mathrm{ha}^{-1}$. Other sulfonylurea herbicides such as thifensulfuron have also shown to cause up to $67 \%$ injury in some market classes of beans [10]. In other studies, halosulfuron POST reduced seed yield of adzuki bean as much as $68 \%$ and white bean as much as $9 \%$ but had no adverse effect on seed yield of black, cranberry, kidney, otebo, pinto and small red Mexican beans [9]. Other studies have also shown that halosulfuron POST can reduce seed yield of white bean as much as $21 \%$ compared to the untreated weed-free control [11]. Sulfonylurea herbicides such as thifensulfuron and chlorimuron applied POST have been shown to reduce dry bean yield as much as $89 \%$ and $93 \%$, respectively [14].

\subsection{Weed Control}

Dominant weeds in this study as determined by quantification and qualification of non-treated control plots included A. retroflexus (AMARE), C. album (CHEAL) and S. arvensis (SINAR). The ANOVA indicated no effect of years or treatment by years for weed control; therefore, data were pooled and averaged for environments (Tables 2-4).

Halosulfuron applied PPI, PRE and POST controlled AMARE 92\% - 95\%, 85\% - 95\% and 65\% - 75\% at 4 WAA and $97 \%-100 \%, 97 \%-99 \%$ and $47 \%-65 \%$ at 8 WAA, respectively (Table 2). Halosulfuron applied PPI, PRE and POST controlled CHEAL 95-98, 83-93 and 36-51\% at 4 WAA and $97 \%-100 \%, 96 \%-99 \%$ and $41 \%-47 \%$ at 8 WAA, respectively (Table 3). Halosulfuron applied PPI, PRE and POST controlled SINAR $97 \%-100 \%, 100 \%$ and $100 \%$ at 4 WAA and $99 \%-100 \%, 99 \%-100 \%$ and $100 \%$ at 8 WAA, respectively (Table 4). In other studies, halosulfuron provided 80\% - 81\% control of AMARE, 91\% - 94\% control of AMBEL, and 36\% control of CHEAL [11]. Other ALS inhibiting herbicides such as imazethapyr and imazamox have provided $76 \%$ to $100 \%$ control of AMARE, AMBEL or CHEAL in dry bean [15]-[17]. Halosulfuron plus fomesa-

Table 2. Percent control, density and dry weight of redroot pigweed (AMARE) in white bean treated with halosulfuron at three different timings at Exeter (2011-2013) and Harrow, ON (2012). Means followed by the same letter within a column are not significantly different according to Fisher's Protected LSD at $\mathrm{P}<0.05^{\mathrm{a}}$.

\begin{tabular}{|c|c|c|c|c|c|c|}
\hline \multirow[b]{2}{*}{ Herbicide Treatment } & \multicolumn{5}{|c|}{ Control } & \multirow[b]{2}{*}{ Dry Weigh } \\
\hline & Rate g.ai $\cdot \mathrm{ha}^{-1}$ & Timing & 4 WAA & $8 \mathrm{WAA}$ & Density & \\
\hline & & & \multicolumn{2}{|c|}{$\%$} & $\# \mathrm{~m}^{-2}$ & $\mathrm{~g} \cdot \mathrm{m}^{-2}$ \\
\hline Weedy check & & & 0 & $0 \mathrm{c}$ & $6.1 \mathrm{e}$ & $30.6 \mathrm{c}$ \\
\hline Weed-free check & & & 100 & $100 \mathrm{a}$ & $0.0 \mathrm{a}$ & $0.0 \mathrm{a}$ \\
\hline Halosulfuron & 17.5 & PPI & 94 & 97 a & $0.2 \mathrm{ab}$ & $0.6 \mathrm{ab}$ \\
\hline Halosulfuron & 35 & PPI & 95 & 97 a & $0.2 \mathrm{ab}$ & $0.9 \mathrm{ab}$ \\
\hline Halosulfuron & 70 & PPI & 92 & $100 \mathrm{a}$ & $0.4 \mathrm{ab}$ & $1.1 \mathrm{ab}$ \\
\hline Halosulfuron & 17.5 & PRE & 85 & 97 a & $1.3 \mathrm{bcd}$ & $4.2 \mathrm{abc}$ \\
\hline Halosulfuron & 35 & PRE & 89 & 97 a & $0.8 \mathrm{abc}$ & $1.5 \mathrm{ab}$ \\
\hline Halosulfuron & 70 & PRE & 95 & 99 a & $0.3 \mathrm{ab}$ & $1.3 \mathrm{ab}$ \\
\hline Halosulfuron & 17.5 & POST & 68 & $47 \mathrm{~b}$ & 5.0 de & $20.6 \mathrm{c}$ \\
\hline Halosulfuron & 35 & POST & 65 & $54 \mathrm{~b}$ & 3.6 cde & $8.5 \mathrm{bc}$ \\
\hline Halosulfuron & 70 & POST & 75 & $65 \mathrm{~b}$ & 3.5 cde & 8.2 bc \\
\hline
\end{tabular}

a Abbreviations: WAA, weeks after POST herbicide application; POST, postemergence; PPI, preplant incorporated; PRE, preemergence. 
Table 3. Percent control, density and dry weight of common lambsquarters (CHEAL) in white bean treated with halosulfuron at three different timings at Exeter (2011-2013) and Harrow, ON (2012). Means followed by the same letter within a column are not significantly different according to Fisher's Protected LSD at $\mathrm{P}<0.05^{\mathrm{a}}$.

\begin{tabular}{|c|c|c|c|c|c|c|}
\hline \multirow[b]{2}{*}{ Herbicide Treatment } & \multicolumn{5}{|c|}{ Control } & \multirow[b]{2}{*}{ Dry weight } \\
\hline & Rate $\mathrm{g} \cdot \mathrm{ai} \cdot \mathrm{ha}^{-1}$ & Timing & 4 WAA & 8 WAA & Density & \\
\hline & & & \multicolumn{2}{|c|}{$\%$} & $\# \mathrm{~m}^{-2}$ & $g \cdot m^{-2}$ \\
\hline Weedy check & & & $0 \mathrm{~d}$ & $0 \mathrm{~d}$ & $10.6 \mathrm{c}$ & $37.5 \mathrm{c}$ \\
\hline Weed-free check & & & $100 \mathrm{a}$ & 100 a & $0.0 \mathrm{a}$ & $0.0 \mathrm{a}$ \\
\hline Halosulfuron & 17.5 & PPI & $96 \mathrm{ab}$ & $97 \mathrm{~b}$ & $1.2 \mathrm{~b}$ & $1.6 \mathrm{ab}$ \\
\hline Halosulfuron & 35 & PPI & $98 \mathrm{ab}$ & $99 \mathrm{ab}$ & $0.2 \mathrm{ab}$ & $0.9 \mathrm{ab}$ \\
\hline Halosulfuron & 70 & PPI & $95 \mathrm{ab}$ & 100 a & $0.5 \mathrm{ab}$ & $1.5 \mathrm{ab}$ \\
\hline Halosulfuron & 17.5 & PRE & $83 \mathrm{~b}$ & $96 \mathrm{~b}$ & $2.0 \mathrm{~b}$ & $4.7 \mathrm{~b}$ \\
\hline Halosulfuron & 35 & PRE & $87 \mathrm{~b}$ & $99 \mathrm{ab}$ & $1.5 \mathrm{~b}$ & $3.4 \mathrm{ab}$ \\
\hline Halosulfuron & 70 & PRE & $93 \mathrm{ab}$ & $99 \mathrm{ab}$ & $0.7 \mathrm{ab}$ & $2.6 \mathrm{ab}$ \\
\hline Halosulfuron & 17.5 & POST & $44 \mathrm{c}$ & $42 \mathrm{c}$ & $9.5 \mathrm{c}$ & $72.3 \mathrm{c}$ \\
\hline Halosulfuron & 35 & POST & 36 c & $41 \mathrm{c}$ & 10.7 c & 48.9 c \\
\hline Halosulfuron & 70 & POST & $51 \mathrm{c}$ & $47 \mathrm{c}$ & $9.4 \mathrm{c}$ & $52.1 \mathrm{c}$ \\
\hline
\end{tabular}

${ }^{\mathrm{a}}$ Abbreviations: WAA, weeks after POST herbicide application; POST, postemergence; PPI, preplant incorporated; PRE, preemergence.

Table 4. Percent control, density and dry weight of wild mustard (SINAR) in white bean treated with halosulfuron at three different timings at Exeter (2011-2013) and Harrow, ON (2012). Means followed by the same letter within a column are not significantly different according to Fisher's Protected LSD at $\mathrm{P}<0.05^{\mathrm{a}}$.

\begin{tabular}{|c|c|c|c|c|c|c|}
\hline \multirow[b]{2}{*}{ Herbicide treatment } & \multicolumn{5}{|c|}{ Control } & \multirow[b]{2}{*}{ Dry weight } \\
\hline & Rate $\mathrm{g} \cdot \mathrm{ai} \cdot \mathrm{ha}^{-1}$ & Timing & 4 WAA & 8 WAA & Density & \\
\hline & & & \multicolumn{2}{|c|}{$\%$} & $\# \mathrm{~m}^{-2}$ & $\mathrm{~g} \cdot \mathrm{m}^{-2}$ \\
\hline Weedy check & & & 0 & 0 & 59.0 c & $161.5 \mathrm{~b}$ \\
\hline Weed-free check & & & 100 & 100 & $0.0 \mathrm{a}$ & $0.0 \mathrm{a}$ \\
\hline Halosulfuron & 17.5 & PPI & 97 & 99 & $0.6 \mathrm{~b}$ & $0.1 \mathrm{a}$ \\
\hline Halosulfuron & 35 & PPI & 99 & 100 & $0.2 \mathrm{ab}$ & $0.0 \mathrm{a}$ \\
\hline Halosulfuron & 70 & PPI & 100 & 100 & $0.3 \mathrm{ab}$ & $0.0 \mathrm{a}$ \\
\hline Halosulfuron & 17.5 & PRE & 100 & 99 & $0.3 \mathrm{ab}$ & $0.0 \mathrm{a}$ \\
\hline Halosulfuron & 35 & PRE & 100 & 100 & $0.0 \mathrm{a}$ & $0.0 \mathrm{a}$ \\
\hline Halosulfuron & 70 & PRE & 100 & 100 & $0.0 \mathrm{a}$ & $0.0 \mathrm{a}$ \\
\hline Halosulfuron & 17.5 & POST & 100 & 100 & $0.1 \mathrm{ab}$ & $0.0 \mathrm{a}$ \\
\hline Halosulfuron & 35 & POST & 100 & 100 & $0.0 \mathrm{a}$ & $0.0 \mathrm{a}$ \\
\hline Halosulfuron & 70 & POST & 100 & 100 & $0.0 \mathrm{a}$ & $0.0 \mathrm{a}$ \\
\hline
\end{tabular}

a Abbreviations: WAA, weeks after POST herbicide application; POST, postemergence; PPI, preplant incorporated; PRE, preemergence.

fen POST provided 89\% - 92\% control of AMARE, 93\% - 95\% control of AMBEL, and 55\% - 59\% control of CHEAL. The tankmix of halosulfuron plus bentazon plus fomesafen also provided 89\% - 91\% control of AMARE, 97\% - 98\% control of AMBEL, and 79\% - 82\% control of CHEAL [11]. 


\subsection{Weed Density and Biomass}

Halosulfuron applied PPI and PRE reduced AMARE density 93\% - 97\% and 75\% - 95\% and AMARE dry weight 96\% - 98\% and 86\% - 96\%, respectively. However, halosulfuron applied POST at rates evaluated caused no significant reduction in AMARE density or dry weight compared to the weedy check (Table 2).

Halosulfuron applied PPI and PRE reduced CHEAL density 89\% - 98\% and 81\% - 93\% and CHEAL dry weight 96\% - 98\% and 87\% - 93\%, respectively (Table 3). However, halosulfuron applied POST at 17.5, 35 and $70 \mathrm{~g} \cdot \mathrm{ai} \cdot \mathrm{ha}^{-1}$ caused no significant reduction in CHEAL density or dry weight compared to the weedy check (Table 3).

Halosulfuron applied PPI, PRE and POST reduced SINAR density 99\% - 100\%, 99\% - 100\% and 100\% and SINAR dry weight $100 \%, 100 \%$ and $100 \%$, respectively (Table 4).

In other studies, halosulfuron applied POST at $35 \mathrm{~g} \cdot \mathrm{ai} \cdot \mathrm{ha}^{-1}$ reduced AMBEL density $100 \%$ but did not reduce AMARE and CHEAL density compared to the weedy check [11]. Similarly, halosulfuron applied POST at 35 $\mathrm{g} \cdot \mathrm{ai} \cdot \mathrm{ha}^{-1}$ reduced AMARE biomass $93 \%$ and AMBEL biomass $100 \%$ but had no effect on CHEAL biomass [11]. Other ALS inhibiting herbicides such as imazethapyr applied alone or in combination with other herbicides have been shown to reduce AMARE and CHEAL density 69\% - 100\% [13]. Similarly, thifensulfuron plus bentazon have been shown to reduce weed biomass $93 \%-100 \%[13]$.

\subsection{Seed Moisture Content and Yield}

The ANOVA indicated no effect of years or treatment by years for white bean seed moisture content and seed yield; therefore data were pooled and averaged for environments (Table 1).

Higher seed moisture content at harvest is an indication of delayed maturity caused by herbicides in dry beans. It can result in increased spoilage due to bacterial and fungal diseases, staining, or increased drying costs, and can result in dockage at the point of sale. There was no difference in seed moisture content between treatments evaluated (Table 1). In other studies seed moisture content were increased $1.8 \%$ to $3.0 \%$ with halosulfuron POST in adzuki, cranberry and kidney bean but there was no effect on the maturity of black, otebo, pinto, small red Mexican and white beans [9].

The level of weed control provided by halosulfuron reduced weed interference resulting in an increase white bean seed yield compared to the weedy check for all treatments except for halosulfuron applied POST at 17.5 $\mathrm{g} \cdot \mathrm{ai} \cdot \mathrm{ha}^{-1}$ (Table 1). The level of weed control provided by halosulfuron applied PPI or PRE at 17.5, 35 and 70 $\mathrm{g} \cdot \mathrm{ai} \cdot \mathrm{ha}^{-1}$ resulted in white bean seed yields that were equivalent to the weed-free check except when applied PRE at $17.5 \mathrm{~g} \cdot \mathrm{ai}^{-h^{-1}}{ }^{-1}$ which resulted in a yield loss of $25 \%$ (Table 1). Weed interference with halosulfuron applied POST at 17.5, 35 and $70 \mathrm{~g} \cdot \mathrm{ai}^{\mathrm{h}} \mathrm{ha}^{-1}$ resulted in a decrease in white bean yield of $47 \%, 42 \%$ and $44 \%$, respectively (Table 1).

\section{Conclusion}

Based on these results, halosulfuron applied PPI or PRE at rates above $17.5 \mathrm{~g} \cdot \mathrm{ai} \cdot \mathrm{ha}^{-1}$ causes minimal and transient injury with no adverse effect on seed yield of white bean. Halosulfuron applied PPI and PRE provided adequate control of AMARE and CHEAL and SINAR. However, halosulfuron POST provided inadequate control of AMARE and CHEAL but provided excellent control of SINAR at rates evaluated. Weed density and biomass generally followed the same trend as visible control. Based on these results, halosulfuron applied PPI or PRE at $35 \mathrm{~g} \cdot \mathrm{ai} \cdot \mathrm{ha}^{-1}$ can be used safely for the control of some broadleaf weeds in white bean production. Further research is needed to ascertain the efficacy and tolerance of other market classes of dry bean with halosulfuron PPI, PRE and POST.

\section{Acknowledgements}

The authors acknowledge Todd Cowan and Elaine Lepp for their expertise and technical assistance in these studies. Funding for this project was provided by the Ontario Bean Growers and the CanAdvance program of Agricultural Adaptation Council.

\section{References}

[1] Kulasekera, K. (2014) Estimated Area, Yield, Production and Farm Value of Specified Field Crops, Ontario, 
2011-2013 (Metric Units). Ontario Ministry of Agriculture, Food and Rural Affairs. http://www.omafra.gov.on.ca/english/stats/crops/estimate_new.htm

[2] Arnold, N.R., Murray, W.M., Gregory, J.E. and Smeal, D. (1993) Weed Control in Pinto Beans (Phaseolus vulgaris) with Imazethapyr Combinations. Weed Technology, 7, 361-364.

[3] Bauer, T.A., Renner, K.A., Penner, D. and Kelly, J.D. (1995) Pinto Bean (Phaseolus vulgaris) Varietal Tolerance to Imazethapyr. Weed Science, 43, 417-424.

[4] Blackshaw, R.E. and Esau, R. (1991) Control of Annual Broadleaf Weeds in Pinto Beans (Phaseolus vulgaris). Weed Technology, 5, 532-538.

[5] Urwin, C.P., Wilson, R.G. and Mortensen, D.A. (1996) Responses of Dry Edible Bean (Phaseolus vulgaris) Cultivars to Four Herbicides. Weed Technology, 10, 512-518.

[6] Wilson, R.G. and Miller, S.D. (1991) Dry Edible Bean (Phaseolus vulgaris) Responses to Imazethapyr. Weed Technology, 5, 22-26.

[7] Ontario Ministry of Agriculture, Food, and Rural Affairs (OMAFRA) (2013) Guide to Weed Control. Publication 75. Ontario Ministry of Agriculture, Food, and Rural Affairs, Toronto.

[8] Senseman, S.A. (2007) Herbicide Handbook, Ninth Edition. Weed Science Society of America, Champaign, 458 p.

[9] Soltani, N., Shropshire, C. and Sikkema, P.H. (2012) Response of Dry Bean to Halosulfuron Applied Postemergence. Canadian Journal of Plant Science, 92, 723-728. http://dx.doi.org/10.4141/cjps2011-220

[10] Stewart, C.L., Nurse, R.E., Gillard, C. and Sikkema, P.H. (2010) Tolerance of Adzuki Bean to Preplant-Incorporated, Pre-Emergence, and Post-Emergence Herbicides in Ontario, Canada. Weed Biology and Management, 10, 40-47. http://dx.doi.org/10.1111/j.1445-6664.2010.00365.x

[11] Soltani, N., Nurse, R.E. and Sikkema, P.H. (2013) Weed Management in White Bean with Postemergence Herbicide Tankmixes. Canadian Journal of Plant Science, 93, 669-674. http://dx.doi.org/10.4141/cjps2012-273

[12] Silvey, B.D., Mitchem, W.E., Macrae, A.W. and Monks, D.W. (2006) Snap Bean (Phaseolus vulgaris) Tolerance to Halosulfuron PRE, POST, or PRE Followed by POST. Weed Technology, 20, 873-876. http://dx.doi.org/10.1614/WT-05-046.1

[13] Wall, D. (1995) Bentazon Tank-Mixtures for Improved Redroot Pigweed (Amaranthus retroflexus) and Common Lambsquarters (Chenopodium album) Control in Navy Bean (Phaseolus vulgaris). Weed Technology, 9, 610-616.

[14] Sikkema, P.H., Soltani N., Shropshire C. and Cowan. T. (2004) Tolerance of White Beans to Postemergence Broadleaf Herbicides. Weed Technology, 18, 893-901. http://dx.doi.org/10.1614/WT-03-043R3

[15] Burnside, O.C., Ahrens, W.H., Holder, B.J., Wiens, M.J., Johnson, M.M. and Ristau, E.A. (1994) Efficacy and Economics of Various Mechanical Plus Chemical Weed Control Systems in Dry Bean (Phaseolus vulgaris). Weed Technology, 8, 238-244.

[16] VanGessel, J.M. and Westra, P. (1997) Economics and Efficacy of Postemergence Spurred Anoda (Anoda cristata) Control in Pinto Beans (Phaseolus vulgaris). Weed Technology, 11, 329-334.

[17] Wilson Jr., R.G. (2005) Response of Dry Bean and Weeds to Fomesafen Tankmixtures. Weed Technology, 19, 201206. http://dx.doi.org/10.1614/WT-04-166R 
Scientific Research Publishing (SCIRP) is one of the largest Open Access journal publishers. It is currently publishing more than 200 open access, online, peer-reviewed journals covering a wide range of academic disciplines. SCIRP serves the worldwide academic communities and contributes to the progress and application of science with its publication.

Other selected journals from SCIRP are listed as below. Submit your manuscript to us via either submit@scirp.org or Online Submission Portal.
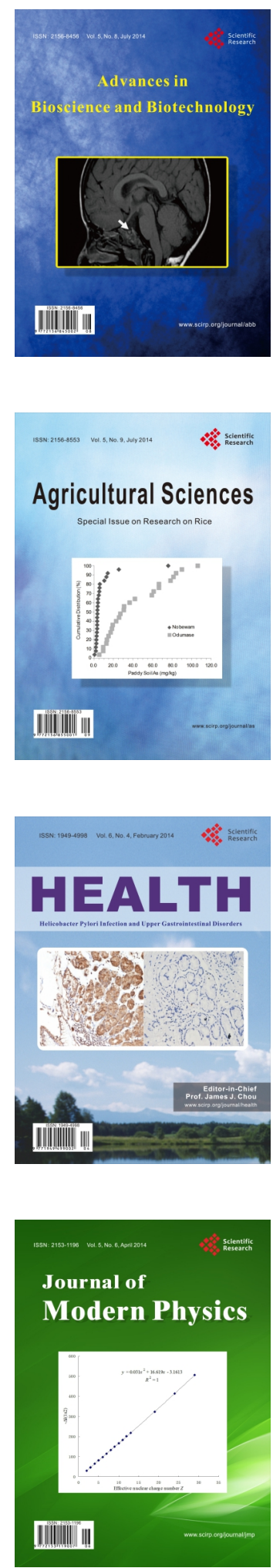
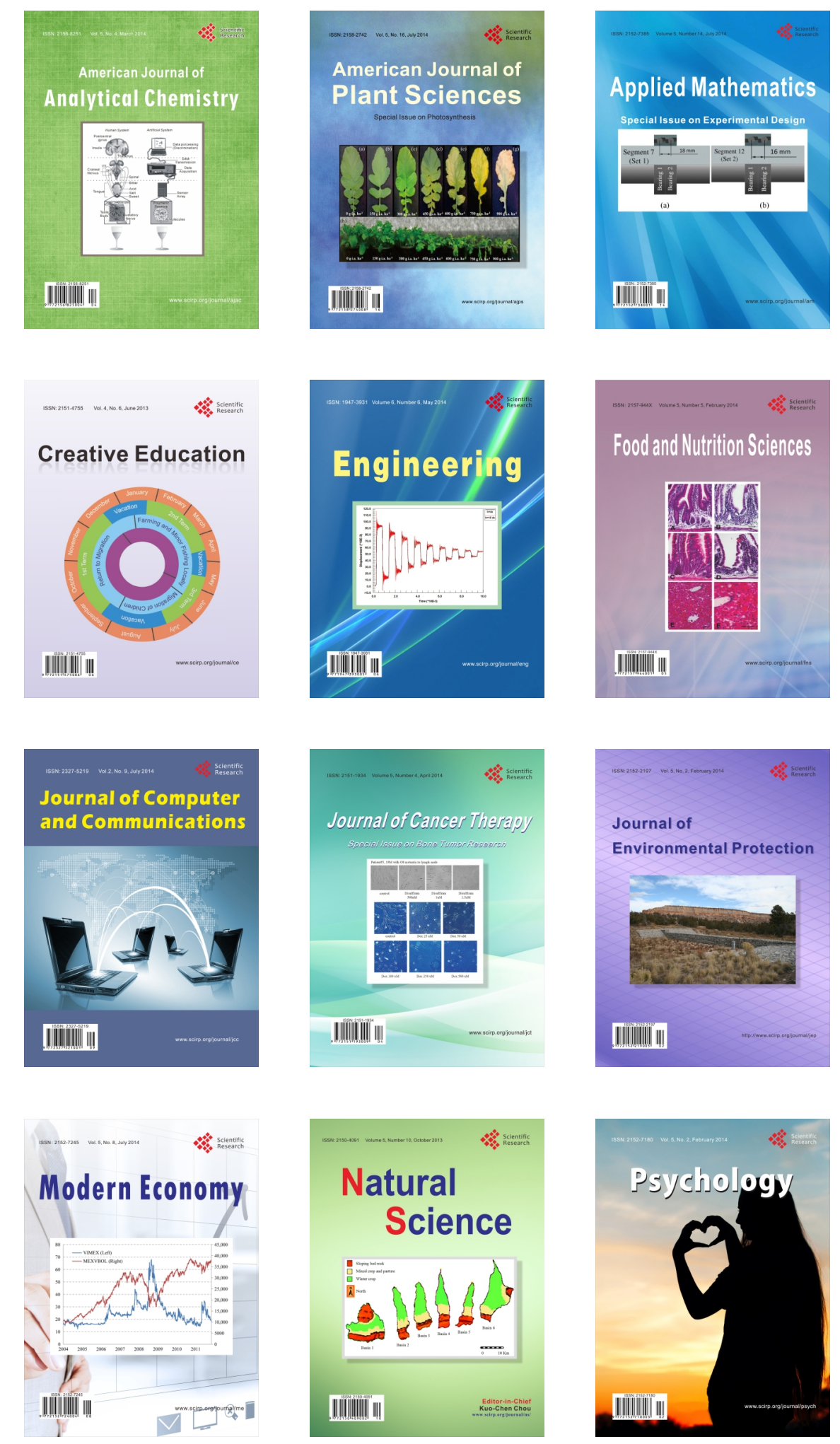